\title{
THE EFFECT OF DHIKR ON ANXIETY AND DEPRESSION LEVEL IN HEMODIALYSIS PATIENTS AT PURWOKERTO ISLAMIC HOSPITAL
}

\author{
Muhamad Anggun $^{1}$, Titik Kusumawinakhyu ${ }^{1}$, Wiharto $^{1}$, Irma Finurina Mustikawati ${ }^{1}$ \\ Faculty of Medicine, Muhammadiyah University of Purwokerto
}

\begin{abstract}
Hemodialysis is a routinely performed therapy on chronic kidney patients, leading to psychological problems among subjects who undergo hemodialysis, such as anxiety and depression. One of the efforts to overcome anxiety and depression is with the dhikr intervention. Dhikr presents hearts to remember and be obedient to Allah followed by the words and actions in various conditions. Discover dhikr's influence on the level of anxiety and depression in patients on hemodialysis in Purwokerto Islamic Hospital. It was a quantitative study using quasi experiment with a non-quivalent control group design. The number of samples was 12 subjects consisting of 6 subjects in the control group and six subjects in the intervention group with the purposive sampling technique. Instruments were used to measure anxiety and depression are the HADS ( Hospital Anxiety and Depression Scale ) before and after dhikr intervention as much as 12 times. Research is carried out in Hemodialysis Unit of Purwokerto Islamic Hospital. Test statistics on research are used paired t-test and independent t-tests. This study showed a decrease in the mean level of anxiety from 5,83 to 1.67 in the experimental group ( $p=0.003)$. The mean level of depression experienced a decline of 9, 67 becomes 4.67 on a group experiment $(p=0.003)$. Dhikr reduces the level of anxiety and depression in hemodialysis patients at the Purwokerto Islamic Hospital.
\end{abstract}

Keywords: Dhikr, Anxiety, Depression, HADS, Chronic Kidney disease, Hemodialysis 


\section{INTRODUCTION}

Anxiety is one of the psychological problems found in patients with Chronic Kidney Disease (CKD). Chronic Kidney Disease needs hemodialysis therapy routinely twice a week for the rest of life (Alshraifeen et al., 2020). Changes in the patient's physical condition of chronic kidney disease certainly influence the quality of life. Hemodialysis is an effort to improve the quality of life of a patient with chronic kidney disease (Kumar et al., 2018). Hemodialysis is a treatment that serves to replace the role of the kidney that operation using a tool specifically to get rid of uremic toxic and set the liquid electrolyte. Measures hemodialysis affect the condition of the physical and psychological in patients with CKD. Psychological effects from hemodialysis therapy which patients experience anxiety and depression (Ardianto \& Elisanti, 2020).

One way to deal with anxiety and depression is with a religious approach. A religious approach obtained by dhikr. Dhikr can have a positive impact in reducing the level of injury (Patimah et al., 2015). Based on previous research were done by Febriani (2012) find that dhikr by using the phrase Subhanallah, Alhamdulillah, and Laaillahaillah, which read as much as 33 times during five-fifteen minutes, can decrease levels of anxiety (Rofieq, 2018). People accustomed to dhikr remember Allah be automatic will respond to expenditure endorphins capable of causing any right feeling happy and comfortable (Patimah et al., 2015) .

The results of Basic Health Research in 2018 the prevalence of anxiety and depression shows $12.3 \%$ of Indonesia's population is aged 15 years and over. The prevalence of anxiety at age adults and the elderly is higher in developing countries, namely 5 0\% (L VIDEBECK, 2011). Based on RISKESDAS 2018, the prevalence of chronic kidney disease in Indonesia amounted to 3,8 percent or a rise of 1.8 percent compared to 2013. According to Indonesia Renal Registry's data in 2017 in Central Java, the patient who recently underwent hemodialysis in 2017 was 2,488, and the patient routine underwent maintenance hemodialysis as many as 866 people in hemodialysis unit of Central Java totaled 89 units ((IRR), 2017). Based on the studies previously were done by (Khan et al., 2019), provide information on the prevalence of depression among patients with disease kidney chronic who undergo hemodialysis obtained results an increase in the percentage level of depression in patients with CKD, $71.3 \%$ on a visit first, $78.2 \%$ in visit both and acquired $84.9 \%$ (Khan et al., 2019). Research other states that patients who undergo hemodialysis generally experiencing depression (Ganu et al., 2018). Based on the results of studies preliminary research in Purwokerto Islamic Hospital, the patients of chronic kidney disease who undergo hemodialysis. Purwokerto Islamic Hospital is one of the referral hospitals in Purwokerto, which has hemodialysis facilities. The hospital is based on Islam, which became the basis for researching the influence of dhikr on the level of anxiety and depression in patients on hemodialysis at Purwokerto Islamic Hospital. 


\section{METHOD}

The method used in this research was a Quasi Experiment (semi-experimental) with the form of a non-quivalent control group design. Research has been done in Hemodialysis Unit of Purwokerto Islamic Hospital from February to March 2020. The research population was patients with chronic kidney disease who undergo hemodialysis at Rumah Sakit Islam Purwokerto period in February-March 2020. The technique of sampling used in the study it is purposive sampling. The method of collecting the study data uses questionnaires Hospital Anxiety and Depression Scale ( HADS ) and the questionnaire dhikr. The analysis that was used is paired t-test and independent t-tests.

\section{RESULTS}

Research was conducted at the hemodialysis unit of Purwokerto Islamic Hospital on February-March 2020. The research subject was 12 patients with chronic kidney disease who undergo hemodialysis. The researcher divided into two groups: the experimental and control group, the number of each experimental group was six subjects, and the control group was six subjects. Data distribution of subjects was collected of gender, age, occupation, and education. A detailed description of the distribution of subjects based on characteristics can be seen in table 1 .

\section{Table 1 . Distribution of subjects based on the following characteristics:}

\begin{tabular}{lcccc}
\hline \multicolumn{1}{c}{ Karakteristik } & \multicolumn{2}{c}{ Kelompok Eksperimen } & \multicolumn{2}{c}{ Kelompok Kontrol } \\
\cline { 2 - 5 } & $\begin{array}{c}\text { Jumlah } \\
\text { (n) }\end{array}$ & $\begin{array}{c}\text { Persentase } \\
(\%)\end{array}$ & $\begin{array}{c}\text { Jumlah } \\
(\mathrm{n})\end{array}$ & $\begin{array}{c}\text { Persentase } \\
(\%)\end{array}$ \\
\hline Jenis Kelamin & & & & \\
$\quad$ Laki-laki & 1 & 16,7 & 3 & 50 \\
Perempuan & 5 & 83,3 & 3 & \\
& & & & \\
Usia & & & 2 & 33,3 \\
46-55 & 4 & 66,7 & 2 & 33,3 \\
$56-65$ & 0 & 0 & 2 & 33,3 \\
$>65$ & 2 & 33,3 & & \\
Pekerjaan & & & 1 & 16,7 \\
PNS & 0 & 0 & 1 & 66,7 \\
Wiraswasta & 1 & 16,7 & 4 & \\
$\quad$ Lain-lain & 5 & 83,3 & & 66,7 \\
Pendidikan terakhir & & & 4 & 16,7 \\
SD & 2 & 33,3 & 1 & 16,7 \\
SMP & 3 & 50 & 1 & \\
SMA & 1 & 16,7 & & \\
\hline
\end{tabular}




\section{Gender}

Based on table 1 . The subjects' distribution based on gender in the experimental group was more female than 5 subjects (83.3\%) and male subjects as many as 1 subject (16.7\%). Whereas in the control group, male and female subjects were the same, namely 3 subjects each (50\%). This study found more data on women than male research subjects. Gender is one of the factors that can influence a person's anxiety and depression. Women experience anxiety more quickly than men. A woman has unstable emotions, so it is easier to worry about body changes that can cause anxiety (Hendrawati H, 2018) . In line with previous research conducted by (Riskal \& Annisa, 2020) based on the female gender, 56.8\% underwent hemodialysis. Previous research conducted by Rahayu H (2019) showed that the most hemodialysis patients were women (52.9\%) . According to (Mosleh \& Alenezi, 2020), anxiety and depression are prevalent among chronic kidney disease patients, especially in women.

\section{Age}

The results of table 1 distribution of subjects based on age are divided into three categories according to the criteria of the Ministry of Health (2009), namely, age 46-55 years (early elderly), 56-65 years (late elderly), and $>65$ years (senior citizens). ). The study results based on age obtained data from the experimental group aged 46-55 years as many as 4 subjects (66.7\%). Subjects who were more than 65 years old were 2 subjects (33.3\%). Whereas in the control group, the subjects aged 46-55 years, 56-65 years, and more than 65 years each were 2 subjects (33.3\%). In this study, the most data obtained were subjects aged 46-55 years. According to the 2018 Indonesian Renal Registry (IRR), most patients undergoing hemodialysis are aged 46-65 years. In line with the research conducted by Ika Hayun Al Azis (2017), the subjects with the highest number were in the elderly age group ( $>45$ years) with a total of 36 subjects $(66.7 \%)$, indicating a relationship between age and anxiety levels in patients with kidney failure who underwent hemodialysis .

\section{Profession}

The subjects' distribution based on work resulted in 5 subjects (83.3\%) of various work experiment groups and 1 subject (16.7\%) as self-employed. Whereas in the control group other work as many as 4 subjects (66.7\%). Self-employed as much as 1 subject $(16.7 \%)$. Civil servants as much as 1 subject (16.7\%). Other occupational categories obtain the most occupational distribution among patients. Work also influences a person's level of anxiety and depression. When someone feels comfortable and happy with their job, their level of anxiety and depression will below, and last education. 


\section{Education}

The distribution of subjects based on the latest education results in the experimental group, the subjects in this study who had junior high school education were 3 subjects (50\%). Subjects with elementary education were 2 subjects (33.3\%), and high school education subjects were 1 subject (16.7\%). Whereas in the control group, the subjects with elementary education were 4 subjects (66.7\%). Subjects with junior high school education were 1 subject (16.7\%), and high school education subjects were 1 subject $(16.7 \%)$. This study found that the most data were subjects with elementary school education. This study's results are by Yuliaw (2009), which states that patients who have higher education will have broader knowledge so that the patient can control themselves in overcoming the problems at hand, have a high sense of trust, are more experienced, and have good predictions. How to deal with events that occur, easy to understand what health workers recommend, and reduce anxiety can help individuals make decisions (Sulistawaty, 2019).

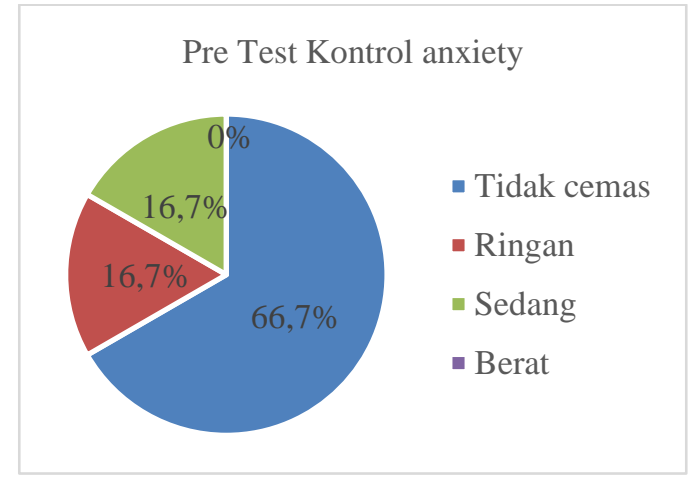

(a)

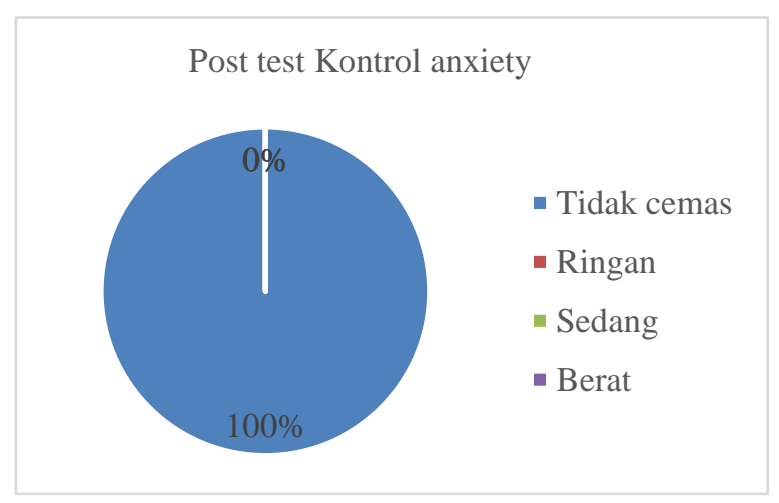

(b)

(b)

Figure 1. a. Pre Test Score Anxiety Level Control Group b. Post Test Score Anxiety Level Control Group

Based on Figure 1.a of the pre-test score for the level of anxiety of the control group the graph above can be seen that for the pre-test score in the control class, as many as four patients $(66.7 \%)$ had a non-anxious value category and one patient $(16.7 \%)$ each had a category mild and moderate anxiety values. Based on Figure 1.b The circle diagram of the post-test score for the control group's level of anxiety above can be seen that for the posttest score in the control class, as many as 6 patients (100\%) have the not anxious score category. 


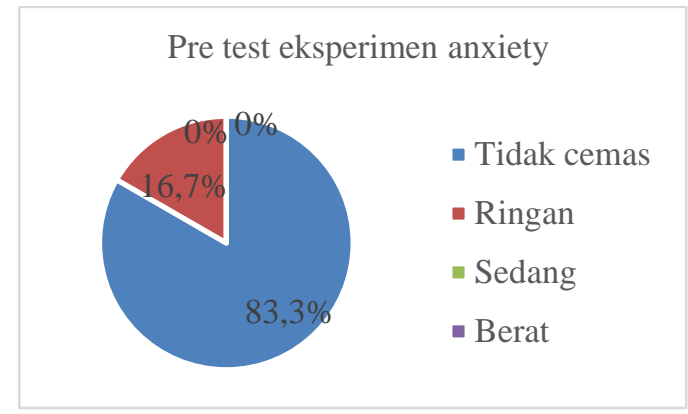

(a)

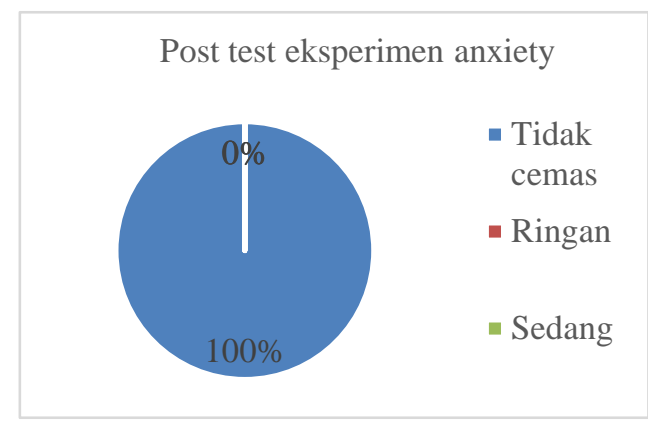

(b)

\section{Figure 2.a Pre-Test Score of Anxiety Level b. Post-Test Score of the Experiment} Group's Anxiety Level

Based on Figure 2.a The circle diagram of the pre-test score for the anxiety level in the experimental group above shows that for the pre-test score in the experimental class, 5 patients $(83.3 \%)$ were not anxious and 1 patient $(16.7 \%)$ had mild anxiety. Based on figure 2.b the post-test score of the experimental group's anxiety level above can be seen that for the post-test score in the experimental group, as many as six patients $(100 \%)$ had the not anxious value category.

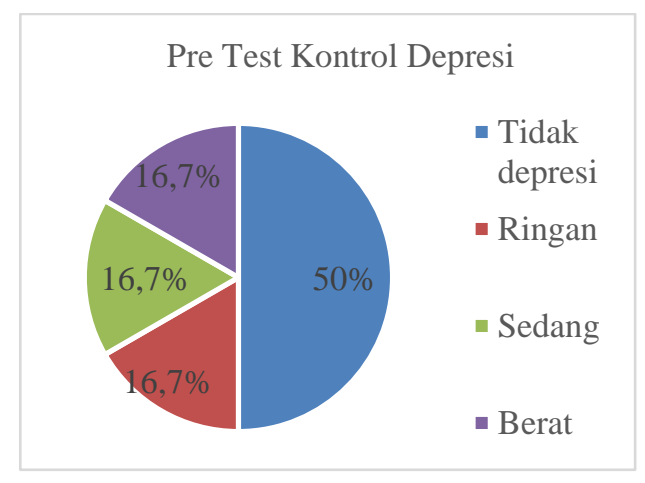

(a)

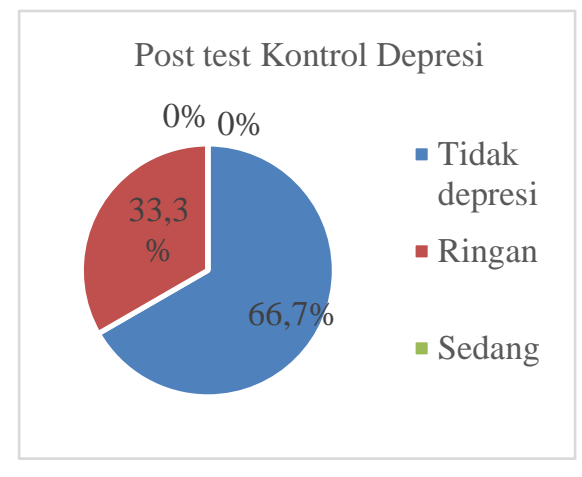

(b)

\section{Figure 3. Pre-Test Score of Depression Level of Control Group; b. Post Test Score of Depression Level of Control Group}

Based on Figure 3.a circle diagram of the pre-test score for the depression level of the control group The graph above can be seen that for the pre-test score in the control group, as many as 3 patients (50\%) had a non-depressed score category and 1 patient each $(16.7 \%)$ had a depression score category. Light, medium, and heavy. Based on Figure 3.b. The circle diagram of the post-test score for the level of depression in the control group above can be seen that for the post-test score in the control class, as many as 4 patients 
(66.7\%) had a non-depressed score category and as many as 2 patients $(33.3 \%)$ had a mild depression score category.

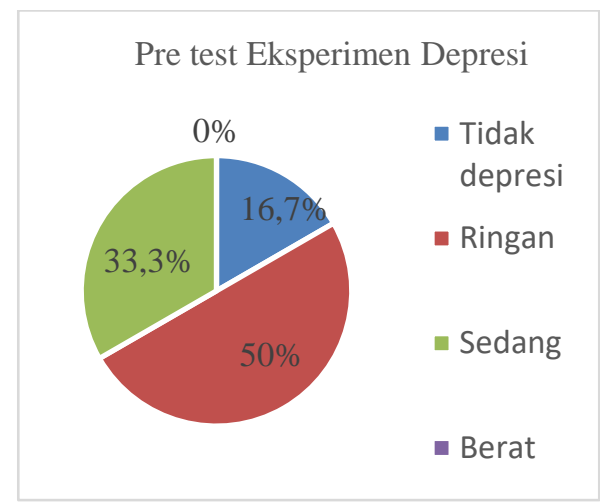

(a)

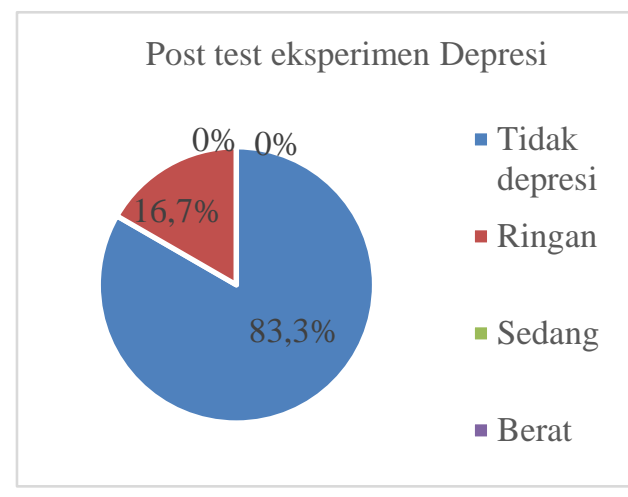

(b)

Figure 4. a Pre-Test Score of Depression Level; b. Post Test Score of Depression Level in Experiment Group

Based on Figure 4.a The circle diagram of the pre-test score for the level of depression in the experimental group above can be seen that for the pre-test score in the experimental group, 1 patient (16.7\%) had a non-depressed score category, as many as 3 patients (50\%) had a mild depression score category and 2 patients (33.3\%) had moderate depression score category. Based on Figure 4.b. The circle diagram of the post-test score for the level of depression in the experimental group above can be seen that for the posttest score in the experimental group, as many as 5 patients (83.3\%) had a non-depressed score category and 1 patient (16.7\%) had a mild depression score category.

This study uses the Paired t-test and independent t-test. The following are the results obtained:

Based on the data in table 4.a. The Paired t-test analysis results of the experimental group above obtained a significant value on the anxiety level variable of $0.031(\mathrm{p}<0.05)$, indicating that there are differences in the scores before and after dhikr therapy of anxiety. The depression variable has a significance value of $0.003(p<0.05)$, which indicates differences in the scores before and after dhikr therapy on the level of depression. The Paired t-test difference obtained in the experimental group the average level of anxiety before the dhikr intervention was 5.83 higher than the level of anxiety after the dhikr intervention was 1.67. Meanwhile, the level of depression before the dhikr intervention was 9.67, higher than the depression level after the dhikr intervention.

Based on the data in table 4.b. The Independent t-test analysis above shows that the significance value of the anxiety level variable is $0.027(\mathrm{p}<0.05)$, which indicates a difference in the anxiety level score of the control group and the experimental group. The depression variable has a significance value of $0.038(\mathrm{p}<0.05)$, which indicates a difference in the depression level score of the control group and the experimental group. 
Based on the data in table 4.b. The Independent t-test results showed that the average decrease in anxiety levels in the experimental group was -4.17 , higher than the control group's decrease in anxiety levels by -1.67 . These results prove that dhikr affects the level of anxiety in hemodialysis patients at the Islamic Hospital Purwokerto. In line with research conducted by Patimah et al ., (2015) proving that dhikr relaxation has a positive impact in reducing the anxiety level of chronic kidney failure (GKD) patients undergoing hemodialysis .

In line with other research conducted by Sulistiyawati (2019), it is found that dhikr therapy can affect reducing anxiety levels. The dzikir sentences read in his research are Astaghfirullahal'adzim , Subhanallah , Laaillaaha illallah , Laa hawlaa walaa kuwwata illa billah. In line with Febriani (2012) research, dhikr was found using the sentences Subhanallah, Alhamdulillah, and Laaillahaillah, which read 33 times for fifteen minutes, can reduce the level of anxiety. According to Perwitaningrum et al. (2016), the results of their research stated that dhikr relaxation training was shown to reduce anxiety levels 21 significantly.

Based on the data in table 4.8, the independent t-test results showed that the average decrease in depression in the experimental group was -5.00 higher than the decrease in depression in the control group of -2.33. These results prove that dhikr affects the level of depression in hemodialysis patients at the Islamic Hospital Purwokerto.

In line with the research conducted by Himawan et al ., (2020) entitled The Effect of Recitation on Depression Levels in Kidney Failure Patients Undergoing Haemodialysis at dr. Slamet Garut. The results showed that dhikr therapy reduces the level of depression in patients undergoing hemodialysis .

Source of Islam's basic subjects and principles as a revelation from Allah that tert money in the Quran .

\section{DISCUSSION}

The Qur'an explains that it is so essential to perform dhikr Allah to reassure the hearts of His believing servants 22 . Allah SWT Surah Ar-Ra'ad 28 means "(that is) those who believe and their hearts are at ease by remembering Allah SWT. Remember, only by remembering Allah SWT will your heart be at peace ".

The role of dhikr in CKD patients undergoing hemodialysis functions to provide relaxation before and after hemodialysis to provide a sense of comfort and positively impact mental health problems in CKD patients undergoing hemodialysis. One way to deal with anxiety and depression is with a religious approach. A religious approach can be made by dhikr. Dzikir is a heart and oral worship that knows no time limit. As much dhikr as possible is recommended in Islam, so there is no time limit for dhikr. Imam Nawawi stated that dhikr is done simultaneously verbally and heart. Allah SWT defines ulil albab, 
are those who always chant their Rab, whether standing, sitting, or even lying down . The dhikr used in this study are as follows:

1) Astaghfirullaa h (3x)

2) Subhannallah (33X)

3) Alhamdulillah (33x)

4) Allahu Akbar (33x)

5) La 'ilaaha illallaahu wahdaahu laasyariikalah, lahul mulku walahul hamdu wahuwa' alaa kullisyai'in qadiir (1x)".

In line with research conducted by Reza (2016) states that the habit of remembering Allah SWT both by reciting tasbih, istighfar, tasbih can make a person feel calm and at ease. Dzikir can bring about psychological balance and result in a state of calm. The parasympathetic system stimulates serotonergic functions to promote a sense of calm 25 . Relaxation response occurs when with dhikr. Dhikr, with full appreciation, will bring the individual to be in a calm and comfortable state.

Dhikr based on previous research conducted by Hamsyah \& Subandi (2017), dhikr readings can calm, arouse self-confidence, feel safe, serene and give a feeling of happiness. Several limitations are lacking in this research, including the minimum number of research subjects on dhikr's effect on levels of anxiety and depression in hemodialysis patients. The study subjects were not patients who had recently undergone hemodialysis but had routinely undergone hemodialysis for 1 year. Researchers do not control the environment when collecting data.

\section{CONCLUSION}

Dzikir reduces the level of anxiety and depression in Hemodialysis patients at the Islamic Hospital Purwokerto. The limitations of this study are for further research to use the research subjects of chronic kidney disease patients who have just undergone hemodialysis with a more significant number of research subjects and can control environmental factors that can affect the level of anxiety and depression in hemodialysis patients. 


\section{REFERENCES}

Alshraifeen A, Alnuaimi K, Al-Rawashdeh S, Ashour A, Al-Ghabeesh S, Al-Smadi A. Spirituality, Anxiety and Depression Among People Receiving Hemodialysis Treatment in Jordan: A Cross-Sectional Study. J Relig Health [Internet] 2020; (0123456789). Available from: https://doi.org/10.1007/s10943-020-00988-8

Mangot AG, Murthy VS. Depression and Anxiety in Patients with Chronic Kidney Disease

Undergoing Hemodialysis. Ann Indian Psychiatry 2017; 1 (March): 51-3.

Infodatin. Chronic Kidney Disease Situation. 2017.

Patimah I, Suryani, Nuraeni A. Effect of Dzikir Relaxation on Anxiety Levels in Patients with Chronic Renal Failure who Underwent Hemodialysis. J Nursing Padjadjaran [Internet] 2015; 3 (April 2015): 18-24. Available from: http://jkp.fkep.unpad.ac.id/index.php/jkp/article/view/95/93

Febriani A. Psychology for Community Welfare. Yogyakarta: Student Library; 2012.

Videbeck. Psychiatric mental health nursing (fifth edition). USA: Lippincott Williams \& Wilkins Inc .; 2011.

Renal Registry. 10 th Report Of Indonesian Renal Registry. 2017;

Khan A, Adnan AS, Sulaiman SAS, Mushtaq S. Prevalence and predictors of depression among hemodialysis patients: a prospective follow-up study. BMC Public Health 2019; 19 (1): 1-13.

Ganu VJ, Boima V, Adjei DN, Yendork JS, Dey ID, Yorke E, et al . Depression and quality of life in patients on long term hemodialysis at a national hospital in Ghana: a crosssectional study. Ghana Med J 2018; 52 (1): 22.

Hendrawati H, Amira Da I. Factors Associated with Anxiety Levels of Pulmonary Tuberculosis Patients at One Hospital in Garut Regency. Sai Betik J Science of Nursing 2018; 14 (1): 21.

Riskal et al . Depression Level Description in Chronic Kidney Disease Patients with Hemodialysis at Siti Rahmah Hospital and DR. Reksodiwiryo Padang. 2019; 11-7.

Rahayu et al . Stress Response of Chronic Kidney Failure Patients Underwent Hemodialysis in the Hemodialysis Room Dr. Hardjono Ponorogo Hospital. 2019;

Mosleh H, Alenezi M, Al johani S, Alsani A, Fairaq G, Bedaiwi R. Prevalence and Factors of Anxiety and Depression in Chronic Kidney Disease Patients Undergoing Hemodialysis: A Cross-sectional Single-Center Study in Saudi Arabia. Cureus 2020; 12 (1): 1-11.

MOH. Age Classification According to Category. Jakarta: DG of Health; 2009.

IRR. 11th Report Of Indonesian Renal Registry 2018. IRR 2018; 1-46.

Al Aziz IH, Sudiro S. The Relationship between Family Support and Anxiety Levels in Chronic Kidney Failure Patients Underwent Hemodialysis AT Dr. Soehadi Prijonegoro Sragen. J Glob Nursing 2017; 2 (1): 56-61. 
Yuliaw A. Relationship between Individual Characteristics and Quality of Life Physical Dimensions of Patients with Chronic Renal Failure at Dr. Kariadi Semarang. 2009;

Sulistyawati et al. Dhikr Therapy for Reducing Anxiety in Cancer Patients. Asia Pac J Oncol Nurs [Internet] 2019; 4 (2): 95-7. Available from: https://www.ncbi.nlm.nih.gov/pmc/articles/PMC5412150/pdf/APJON-4-127.pdf

Perwitaningrum et al . Effect of Dhikr Relaxation Therapy To Reduce Anxiety Levels in Dyspepsia Patients. J Psychological Intervention 2016; 8 (2): 147-64.

Himawan F, Suparjo S, Cuciati C. The Effect of Recitation Therapy on Depression Levels in Kidney Failure Patients Undergoing Haemodialysis. J Holist Nurs Sci 2020; 7 (1): 10-

Rivani H. RELATIONSHIP OF ISLAMIC RELIGIOUS BELIEFS ON THE ACCEPTANCE OF THE RUBELLA MEASLES VACCINE IN THE WORKING AREA OF KEMBARAN I BANYUMAS Health Center, Central Java Province, 2016). powders and solvents. The MR vaccine can be given to children aged 9 months to. J Islamic Thinkers 2019; 20 (1): 3851.

Ariadi P. Mental Health in Islamic Perspective. Syifa 'Med J Medicine and Health 2019; 3 (2): 118.

Jalaluddin Rahmat. The Road To Allah - Stages of the Spiritual Journey to God The third mold. Mizan and Muthahhari Press; 2008.

Ismail Nawawi. Soul Cleansing Treatise: Physical \& Inner Behavior Therapy in the Perspective of Sufism. Surabaya: Karya Agung; 2008.

Reza IF. Implementation of Coping Religious in Overcoming Physical-Psychic-SocialSpiritual Disorders in Chronic Kidney Failure Patients. Intizar 2016; 22 (2): 243.

Saniotis A. Understanding Mind / Body Medicine from Muslim Religious Practices of Salat and Dhikr. J Relig Health 2018; 57 (3): 849-57.

Utami TN. Literature Review of Recitation Mechanisms on Health: Immune Response. J JUMANTIK 2017; 100 (1).

Hamsyah F, Subandi. Dzikir and Happiness: A Mental Health Study on An Indonesian Muslim Sufi Group. J Spiritual Ment al Heal th [Internet] 2017; 19 (1): 80-94. Available from: http://dx.doi.org/10.1080/19349637.2016.1193404 